\section{Az önkormányzat és a nonprofit szervezetek kapcsolata Siklós város példáján}

\section{A dolgozat hátteréül szolgáló kutatásról}

$\mathrm{T}$ émánkat egykori olvasmányélményünk ${ }^{1}$ alapján választottuk. A Központi Statisztikai Hivatal által megjelentetett könyv, pontosan ezt a témát dolgozta fel 2000-ben, és egy korábbi, 1996-os kutatást vett alapjául - melyben a 3149 önkormányzatnak küldött kérdőívben² információt kértek az önkormányzat által juttatott pénzügyi támogatások mértékérôl, összetételéről, a támogatott szervezetek számáról és tevékenységérôl, természetbeni segítségrôl, valamint a szektorból érkezố különbözổ formájú hozzájárulásokról - és, amely kutatás az önkormányzatok és nonprofit szervezetek kapcsolatát elsố ízben vizsgálta.

„Az akkori felmérés eredményei azt mutatták, hogy a magyar települések többségében intenzív és sokrétű kooperáció zajlott, ugyanakkor a kapcsolatokkal nem rendelkezố önkormányzatok magas aránya, illetve a különbözô együttmúködési formák alternatív és korántsem teljes körû elterjedése sejteni engedte, hogy ez a fejlődési folyamat még korántsem zárult le..." (Sebestény, 2002:15). A 2000-re vonatkozó adatgyűjtés szerint továbbá, az önkormányzatoknak már csak 20\%-a állította, hogy semmilyen kapcsolata sincs nonprofit szervezetekkel, míg 1996-ban ez az arány közel 30\%-os volt.

A könyv tehát lényegében egy összehasonlító, leíró jellegú kutatást mutat be, mely egyben feltárja az eltelt idốszakban bekövetkezett változásokat is.

Ezek alapján, kutatásunk fókuszába a siklósi nonprofit szervezeteket, és a helyi önkormányzattal való együttmúködésük feltárását állítottuk. A szervezetek kapcsolatrendszerét több megközelítésbôl is megvizsgáltuk. Az elsổ lépés az anyaggyújtés volt, mely során Siklósról általában - Siklós város története, elhelyezkedése, gazdasági, társadalmi, politikai, demográfiai jellemzói, egyesületi múltja stb. - és a témánkhoz kapcsolódóan - helyi nonprofit szervezetek száma, vezetôik neve, elérhetôsége, tevékenységi körük szerinti beosztása stb. - tájékozódtunk és gyújtöttünk adatokat. A módszer alapvetôen interjúzásból és helyi anyaggyưjtésból állt. Ezután közösen elkészítettük a nonprofit szervezeteknek, illetve az önkormányzatnak szánt interjúk vázlatait.

A módszertan tehát, a megelôző szakirodalomra, az összegyưjiött elôzetes ismeretekre, illetve a Siklóson - az önkormányzattal és több nonprofit szervezettel - készített interjúkra épült, és ezekre támaszkodva igyekeztünk feltárni a helyi, települési önkormányzat és a nonprofit szervezetek kapcsolatát.
Hipotézisünk - eddigi ismereteinkre alapozva - szerint Siklóson:

- az önkormányzatok és nonprofit szervezetek kapcsolata gyenge, azaz legfóbb „érintkezési felületüket”, az önkormányzat által a nonprofit szervezeteknek nyújtott anyagi támogatás adja;

- történeti hagyományaik ellenére, a szervezetek között való produktív együttműködésre példát nem, vagy csak elvétve találunk;

- a nonprofit szervezetek nem képesek hatékony együttmúködésre, így érdekérvényesítésre sem. Céljaik elérésében, múködésükben, tevékenységük kifejtésében, ezáltal korlátozva vannak.

\section{Siklós egyesületi múltja}

társadalmi egyesülések formáit alapvetôen a nemzeti hagyományok (dalárdák, Lolvasókörök), a gazdaság (ipartestületek), társadalom (tűzoltóság, temetkezés) változó szükségletei, illetve az osztály-, réteg- és csoportérdekek (érdekképviseletek) határozták meg. A dualizmus alatt Siklóson körülbelül 35-37 egyesület múködött. 1888-tól hetilap jelent meg a nagyközségben (a megyében Pécs után másodikként). Az egyesületi élet a fokozódó háborús készültség és az ebből fakadó, az egyesületek mûködésére vonatkozó, egyre szigorúbb és korlátozóbb rendelkezések folytán 1912-től ${ }^{3}$ megtorpant, késóbb megszűnt. Az elsổ világháború kitörése után pedig, néhány szociális és tûzoltó egylet kivételével minden egyesület beszüntette tevékenységét. Ám az 1920-as évektốl újra fellendült az egyesületi élet. 1924-ben már újra 23 egyesület múködött. A megmaradtak mellett új, más típusú egyesületek alakultak. (Nagy, 2000) „Az egyesületek első világháború utáni jellegzetes csoportját alkották a katonai, bajtársi és politikai egyesületek. A trianoni békeszerzôdés 112. cikkelye megtiltotta a katonai egyesületek létrehozását, ezért ilyen céllal sportegyesületek alakultak. Közülük a legismertebbek a levente- és a polgári lövészegyesületek”. (Nagy, 2000: 298-299.) Siklóson máig múködik, de nem közvetlenül ennek utódjaként, ugyanis a második világháború elôtt ezeket betiltották, és ilyen irányú gyakorlatok vezetését a katonaság vette át. Az 1945 utáni változások nem kedveztek a spontán társadalmi szervezôdéseknek. „Már létükkel is reakciósnak számítottak a baloldali pártok számára. Elốször a szélsőjobboldali társadalmi szervezeteket szüntették meg rendeleti úton. Az új hatalom szemében azonban gyanúsak voltak a különbözổ felekezetű egyházi egyesületek is, sốt a baloldal fokozatos elôretörésével egyáltalán az egyesületek voltak a hatalom számára kényelmetlenné, mert nehezen lehetett ellenôrizni ốket". (Rozs, 2000, 322)

1970-tổl a nagyközség dinamikus fejlôdésnek indult, az infrastruktúra jelentôs fejlesztésével, majd Máriagyủddel való összevonásával (népszavazás után) 1977-ben városi rangra emelkedett. A ma is tapasztalható élénk egyesületi élet csak 1989 után kezdett ismét fellendülni. Napjainkban, többek között a Siklósi kistérség központjaként tölt be fontos szerepet a megye és a térség életében. 


\section{Együttmúködési formák, lehetőségek}

„A hazai nonprofit szektor a nyolcvanas évek végén végbemenô újjászületése óta többszörösére növekedett, és az összetétele is megváltozott. A gomba-módra szaporodó alapítványok ma már a szervezetek harmadát alkotják, ugyanakkor újabb formák is megjelentek, mint a közalapítványok, köztestületek, közhasznú társaságok. Átalakult a tevékenységi szerkezet is, a hagyományos területek - sport-, szabadidôs egyesületek, érdekképviseletek - mellett, egyre jelentôsebbé vált a kultúra, oktatás, szociális szolgáltatás, az egészségügy és településfejlesztés.

Ezek a feladatkörök a települési önkormányzatok tevékenységében is kiemelkedô helyet foglalnak el. A rájuk háruló terhek, valamint a szủkös költségvetés adta nehézségek enyhítésében fontos szerep jut a rugalmasabb és kisebb apparátussal dolgozó alternatív szolgáltató szervezeteknek. Az állam szociálpolitikai, egészségügyi, kulturális, oktatási kiadásainak csökkentése nyomán a nonprofit szervezetek szerepvállalása várhatóan még tovább bôvül. Az intézményesített vagy hallgatólagos feladatmegosztás, illetve -átadás, a speciális igények kielégítése miatt felmerülô anyagi terheket azonban a szektor pusztán saját erôforrásaiból nem képes fedezni. Ezért a nonprofit szektornak cél szerint nyújtott központi költségvetési támogatás mellett arra is szükség van, hogy a helyi önkormányzatok saját pénzalapjaikból is biztosítsanak anyagi vagy természetbeni segítséget.” (Sebestény, 1998: 10.)

A következôkben bemutatjuk az önkormányzatok és a nonprofit szervezetek közötti - az említett kutatásban is kiemelt - kapcsolati formákat. Ezek tárgyalása során röviden ismertetjük az egyes formákhoz kapcsolódóan a könyv és a saját kutatásunk (ezek mindig a 2004-es évre vonatkoznak) révén szerzett tapasztalatainkat, és e kettốbốl vonunk le egyfajta konklúziót.

\section{Önkormányzati vagy közös alapítású nonprofit szervezetek}

z önkormányzatok az alapítványok, közalapítványok kétharmadát önállóan, a Atöbbit társalapítóként hozták létre. A kutatás az eredmények alapján azt szûrte le, hogy ezek a szervezeti formák helyileg a városokhoz és a nagy lélekszámú településekhez kötôdnek. Az önkormányzati részvétellel létrehozott alapítványok közül a városokban nagyjából minden ötödik szűnt meg.

Az önkormányzatok mintegy 20\%-a közhasznú társaságok (továbbiakban Kht.) létrehozásában is részt vett. Utóbbiak a 2000-es vizsgálatig működôképesebbnek bizonyultak, hiszen a felszámoltak aránya csak $5 \%$ volt. Bár azt is fontos megjegyezni, hogy a jelentôs tőkét igénylő közhasznú társaságok alapítására 2000-ig csak kevés számú önkormányzat vállalkozott. Továbbá a kutatások tekintetében elmodható, hogy az alapítványok kétharmada 1996-ig létrejött ${ }^{4}$, s az ezt követô években nagyjából egyenletes arányban jöttek létre. A közhasznú társaságoknak csak mintegy negyede alakult meg 1996-ig, ettôl kezdve azonban számuk folyamatosan nótt ${ }^{5}$. (Sebestény, 2002)
Siklós város önkormányzata két alapítványt hozott létre: a Siklósi Könyvtárért Közalapítványt (2000 óta müködik, célja a könyvtár állományának fejlesztése) és a Siklós Városért Alapítványt. Utóbbit felszámolták, mivel, mint Kozma Sándor alpolgármester úr elmondta, nem tudta kifejteni tevékenységét - célja a város fejlesztése lett volna -, így tartalékainak felélésével az alapítványt az önkormányzat megszüntette. Siklóson ezen kívül vannak még a településen múködő oktatási intézményekhez kapcsolódó alapítványok (ezeket a szülôk hozták létre), és két szociális tevékenységet folytató alapítvány valamint kettố közhasznú társaság múködik. Az egyiket az önkormányzat a településfejlesztés céljával hozta létre, a másik, pedig a Siklósi Várszínház Kht., melyben az önkormányzati közremúködés nem tisztázott.

Az alpolgármesterrel készített interjúból kiderült, hogy az önkormányzat tagja az Önkormányzatok Szövetségének, de többet sajnos nem tudott felsorolni.

\section{Szerződéses feladatellátás}

helyi önkormányzatok feladataik megosztása vagy átadása érdekében szerzôdést - löthetnek nonprofit szervezetekkel, az utóbbiak ennek fejében anyagi támogatáshoz juthatnak.” (Sebestény, 2002: 22.) Míg 1996-ban az önkormányzatoknak csak mintegy $11 \%$-a, addig 2000-ben már 20\%-a élt ezzel a lehetôséggel. A megállapodások 85\%-át az oktatás, a sport, a kultúra, az egészségügyi, a szociális szolgáltatás, a fejlesztés, továbbá a sport és szabadidổ terén tevékenykedő nonprofit szervezetekkel kötötték meg - a bûnmegelôzésben a kooperációk részaránya ugrásszerűen megnôtt. A szerzốdéses feladat ellátás az önkormányzat és a nonprofit szervezetek között intézményes formája az együttmúködésnek, melyet törvényes keretek között zajlik. (Sebestény, 2002)

2004-ben a siklósi önkormányzat hat nonprofit szervezettel állt szerzôdéses kapcsolatban. Mindegyik, egy-egy kardinális pontja a helyi civil szektornak. A szerzódố felek közül a legkiemelkedóbb támogatásban a siklósi kézilabda egyesület és a siklósi futball klub részesült. A Társadalmi Egyesülések Szövetsége Siklósi Szervezete biztosítja a nonprofit szervezeteknek, kluboknak, köröknek, a Dél-Baranya Televíziónak és a Civil Fórumnak a megfelelő helyet, múködésükhöz; a siklósi Teleház és a Tenkes Népfôiiskola részére infrastruktúrát biztosít. Szerzôdéssel kívánja, a nagy múltú Siklósi Polgárốr Egyesület talpra állítását elősegíteni, hogy a helyi polgári önkéntesek ismét segíthessék a rendôrség bünmegelőző munkáját, a rendfenntartást. Ugyancsak szerzôdés szerint biztosít anyagi támogatást a Tenkes Vegyeskari Egyesületnek, akik versenyeken való részvételük révén viszik a város hírét szerte az országban. Végül, de nem utolsó sorban a Siklósi önkormányzat is csatlakozott a Dél-Dunántúli Regionális Forrásközpont Kht. „Újra dolgozom” és „Lépésról lépésre” programjaihoz. Ezek múködéséhez is anyagi támogatást biztosít, szerzốdéses feladatvállalás keretében.

Megállapíthatjuk, hogy Siklós önkormányzata is elsôsorban a sport, szabadidôs, a kulturális, bűnmegelôzési és a szociális ellátás terén tevékenykedổ szervezetekkel kötött szerzôdést. Az alpolgármester ezt a szervezetek hatékonysági fokával (tömegbázis) és elért eredményeivel magyarázta. 


\section{Közös pályázat, pályázás}

A önkormányzatok számára pótlólagos bevételi források, megszerzésére nyújt lehetôséget, ha a helyi nonprofit szervezetekkel közösen... nyújtanak be pályázatot. Erre azonban 2000-ben csak a települések 6\%-ában volt példa." (Sebestény, 2002: 23.) Siklóson hasonló helyzetet tapasztaltunk. A különbözổ egyesületekkel készített interjúkból kiderült, hogy a szervezetek nemhogy közösen nem pályáznak az önkormányzattal (bár erre egy példát mégis fel tudunk hozni, hiszen éppen ottlétünkkor derült ki, hogy egy PHARE-pályázaton - amin az önkormányzatoknak civilekkel együtt lehetett csak pályázniuk - nyertek), de maguk sem igen veszik igénybe ezt a lehetôséget. Az indokok között általában a megfelelő technikai felszerelés, kellố mennyiségú önrész és szaktudás hiányosságát említik - leggyakrabban a hármat együtt. Amelyik szervezet mégis pályázik, inkább az állami pályázatokat említi, s csak az erôs, hatékony szervezetek (Villány-Siklósi Borút Egyesület) merészkednek az Európai Uniós pályázatok területére.

A siklósi önkormányzat sem nyitott eddig a nonprofit szervezetek felé, bár most némi elôrelépés volt tapasztalható. Nem sokkal kutatásunk elổt került az önkormányzathoz egy hivatásos pályázatírónô, akinek személyében megjelent az elmozdulás lehetốsége a közös pályázás terén (lásd korábban említett uniós pályázat).

A Teleház vezetôje elmondta, hogy tervezi egy fổ pályázatíró felvételét, amennyiben erre sor kerülne, nagyban fellendíthetné a helyi nonprofit szervezetek múködését, esetleges összefogását és lehetôségeket céljaik megvalósításában.

\section{Pénzügyi támogatások}

pénzügyi hozzájárulás a legjellemzóbb formája az önkormányzatok és a Inonprofit szervezetek közötti kapcsolatnak. Ebben a tekintetben, a kutatás szerint 1996 óta nem történt jelentốs elmozdulás. Az önkormányzatok leggyakrabban eseti támogatás formájában nyújtanak pénzügyi támogatást. Ebben az esetben azonban megfigyelhetố, hogy az önkormányzatok nagyobb mértékben támogatták a saját alapítású vagy a velük szerzôdésben álló szervezeteket. Mára szinte teljesen elterjedt, hogy az önkormányzat helyi pályázat meghirdetése útján biztosít a településen mưködố nonprofit szervezetek számára pénzügyi támogatást. (Sebestény, 2002) A vizsgálat (Sebestény, 2002) szerint, azonban ezen a csatornán általában kisebb összeghez jutottak csak a helyi szervezetek. A legnagyobb támogatott kört az egyesületek alkották (nem meglepô, hiszen ezekből van a legtöbb), azonban a támogatás alig 40\%-a jutott hozzájuk, míg 36\%-a közhasznú társaságokhoz (általában részben vagy teljesen önkormányzati alapítású, hiszen nagy alaptôkét igényel) áramlott. Az önkormányzatok által leginkább preferált nonprofit szervezetek azok voltak, amelyek szabadidố eltöltést és sportolási lehetôséget tudtak biztosítani, ezeket követték a településfejlesztést megcélzók, majd a szociális vagy egészségügyi és a különbözô polgár-érdekvédelmi és tűzoltó tevékenységet megcélzók. A legkevesebb támogatás a kultúra, az oktatás-nevelés ügyére, az idősgondozást, az ifjúsághoz kötôdố feladatok ellátását vállalóknak jutott. (Sebestény, 2002)

Siklós önkormányzata is a pályázaton elnyerhetố anyagi támogatás eszközével él elsố sorban. Idén (2004) harmincegy pályázat érkezett be az önkormányzathoz. Az eredmények ismételten a kutatást igazolják. A legnagyobb mértékben a sport, szabadidős tevékenységû, illetve az önkormányzattal szerződésben álló szervezeteket támogatták, a többi szervezet átlagosan 10-30 ezer forintnyi támogatásban részesült. A siklós önkormányzat az elnyerhetố támogatásra szánt teljes összeget (16 millió forintot) két részre osztotta. A pályázó 25 nonprofit șzervezet között 2, míg az ugyancsak pályázó 6 sportegyesület között 14 millió forintot osztott ki. Ezt az elosztást azzal indokolták, hogy a nagyobb tömegbázisú szervezeteket jobban kell és érdemes támogatni, valamint a sport terén elért, illetve várható eredményeknek a város nagy hasznát veszi.

\section{Természetbeni támogatások}

$\mathrm{M}$

1996-ban még nem, 2000-re már általánossá vált a városokban, hogy a hely nonprofit szervezetek használatba vették az önkormányzati ingatlanokat, inf rastruktúrát, szellemi tôkét - ezek a leggyakoribb formái a természetbeni támogatásnak. (Sebestény, 2002)

Siklós önkormányzata a papírforma szerint, ennek nagymértékben eleget tesz. A legtöbb egyesület és az önkormányzat is megjelölte a támogatás fent említett három formáját. Ezért úgy gondoljuk - mivel mindkét oldalról megerốsítést kaptunk -, hogy ezt megvalósult és múködóképes támogatási formának tekinthetjük.

\section{Nonprofit hozzájárulás}

nonprofit szervezetek, - hiszen létrejöttük is alapjában ezt célozza meg -, teAvékenységükkel támogatják a helyi önkormányzatokat feladataik ellátásában, ugyanakkor lehetôség szerint, anyagi támogatással és önkéntes munkával is segíthetik azt. (Sebestény, 2002)

Siklóson, az önkormányzatnak nyújtott anyagi támogatásról nem tudok, viszont a Polgárốrség tagjai több száz órányi önkéntes munkával segítették a város önkormányzatát (a már említett bűnmegelőzési feladatok ellátásával, illetve az illegális szemétlerakó helyek felkutatásával). Az önkéntes munkavégzés arányának növekedéshez szélesebb lakossági megmozdulásra volna szükség - a nonprofit szervezeti tagságon keresztül A nonprofit szervezetek széles polgári tagságának növelése a közösségszervezés egyik alappillére. A szervezetek programjai többségben a helyi társadalom környezetének építését, szépítését szolgálják. Emellett a helyi társadalmi kapcsolatokat is mélyítik, 
erôsítik. A fokozódó közösségi élet és együtt gondolkodás multiplikáló hatását a dinamikusan fejlôdő - a helyi tôke maximális kihasználása, folyamatos pályázás, stb. - település képe tükrözi vissza.

\section{Politikai részuétel}

ivel a nonprofit szervezetek az adott településen, a más formában (állami, gazdasági, önkormányzati) ki nem elégített szükségletekre fókuszálva jöttek létre elsôsorban, így fontos, hogy részt vehessenek a helyi önkormányzatok döntés-elôkészítố munkájában - úgy is, mint a lakosság szócsöve. Bár a nonprofit szervezetek alapszabályukban rögzítik az elvet, miszerint politikai pártállástól mentesek maradnak, ennek áthágása, a fennmaradás, az érdekérvényesítés érdekében, sokszor elkerülhetetlen. (Sebestény, 2002)

Siklóson a polgármester jár élen ezzel a példával, ugyanis ő a Villány-Siklósi Borút Egyesület elnöke. De a többi civil szervezet alapítóiról is általában elmondható, hogy jelentôsebb közéleti szerepet töltött be a város életében a rendszerváltozás előtti és/ vagy utáni időkben. A helyi képviselók szinte mindegyike, tagja egy, de nem ritkán több helyi egyesületnek is - az sem ritka, hogy az adott egyesületben elnök vagy alapító tag. Az önkormányzat két héttel a testületi ülések elổt kiértesítette a helyi nonprofit szervezetek képviselóit, de az ülések napirendi pontjai annyiszor és annyit változtak, hogy ez az út járhatatlannak bizonyult. Az alpolgármester a meghívók elmaradását nem tartja visszalépésnek, hiszen az ülések nyitottak mindenki számára, és napjukat mindig közzé is teszik. Másfelól, úgy vélekedik, hogy mindig mindenkit meghívni felesleges, így azt a gyakorlatot tartja követendônek, hogy mindig csak az érintetteket vonják be döntés-elókészítố munkájukba.

\section{Kapcsolattartás, együttmúködési formák a városban}

közösség érdekében végzett munka során a helyi civil társadalom és a telepüAlés vezetése között számos intézményes együttmúködési forma alakulhat ki." (Sebestény, 2002: 38.) Ezek az alábbiak lehetnek:

- Nonprofit szervezetek önkormányzati döntés-elókészítô munkájába való bevonása. Intézményes egyeztetổ fórum kialakítása - mely lehetôséget biztosít a nonprofit szervezeteknek az önkormányzat vezetőivel való közvetlen tárgyalásra.

- Civil ház (Teleház), közösségi központ működtetése

- Civil referens alkalmazása az önkormányzatnál - mely tisztség az önkormányzatok és a helyi nonprofit szervezetek közötti kapcsolattartást segíti elô

- Nyilvántartás készítése a településen múködô nonprofit szervezetekról

- Önkormányzati sajtótermék megjelentetése - melyben legalább alkalmanként lehetôséget biztosít a nonprofit szervezeteknek a megjelenésre.
Elméletileg múködik intézményes civil fórum a siklósi Teleházban, ám erre vonatkozólag kielégító információval nem szolgálhatunk, és az gondoljuk, hogy a helyi nonprofit szervezetek és az önkormányzat közötti „eszmecserék” inkább informális keretek között zajlanak, tekintve, hogy Siklóson a levont tapasztalatok alapján a város közéleti szereplői egy bonyolult ismeretségi hálója alakult ki és irányítja a várost.

Teleház van Siklóson, a város központjában helyezkedik el. Több nonprofit szervezetnek és körök, klubok rendezvényeinek ad otthont, ugyanakkor biztosítja a helyiek számára a kielégítố technikai felszerelések (nyomtató, fénymásoló, számítógépek, Internet stb.) használatának lehetôségét is.

Civil referens az önkormányzatnál nincs, de van nyilvántartásuk a helyi nonprofit szervezetekről. Kérdésünkre, hogy szerintük hány nonprofit szervezet múködik a településen, azt válaszolták, hogy az adataik szerint mintegy 30 szervezet van a városban. A többit hivatalosan nem ismerik, vagy nem ismerik el. Magunk, a be nem jegyzettekkel együtt úgy 50-re becsüljük a számukat, elôzetes adatgyújtéseink birtokában.

\section{A sajtó}

civil vagy nonprofit szervezetek, egyáltalán a helyi közösségek munkásságának, Aeredményeiknek a bemutatása, nyilvánosságra hozatala nagymértékben kötődik a sajtóhoz, annak valamelyik - írott vagy elektronikus - formájához. (Sebestény, 2002) Nagymértékben segítette a helyi szellemi életet az elsố nyomda megalapítása ${ }^{6}$, mely különbözổ kiadványok (cikkek, könyvek, hetilapok, helyi szerzók könyvei) kiadását segítette elő (Kiss, 2000: 220.). Sajnos a siklósi sajtó olvasótábora olyannyira szúk volt, hogy napi lapok nem igen éltek meg a településen. Az elsố világháborúig mintegy öt hetilapot említenek. Ezek közül a legtartósabban fenn maradt újság a Siklós és Vidéke $e^{7}$ címú, amely elsố sorban közérdekú, társadalmi és szépirodalmi heti lap volt Néplapként indult és az is maradt egész fenn állása alatt. A helyi polgárság érdekeit, igényeit kiszolgáló, a külvilág eseményeit „sajátos” módon tálaló újság. A több mint harminc évig létező újság nagyon jó kordokumentumként szolgálhat a helyi életról. Az elmúlt évtizedekben mindig volt valamilyen kézzel fogható sajtója Siklósnak. De sajnos egyre kevesebb, pedig érdeklődés lenne iránta. A legutóbbi 2001 tavaszán szűnt meg, az 1989-tốl megjelenố számainak könyvtári feldolgozásából kiderült, hogy a lap hasábjain meglehetốs gyakorisággal jelentkeztek a nonprofit szervezetek híreikkel, információikkal.

Jelenleg nincs nyomtatott sajtója (érdemben annak nevezhetó) Siklósnak. Ebból az okból kifolyólag nagyon kevés felületen tudnak megjelenni bármilyen okból is az eredményeikkel. A megyei lapok, a helyi televízió és rádió nem „felület” a szervezeteknek. Bár a kutatás során az derült ki, hogy a szervezetek (elenyészố ellenkezố véleményt találtunk) alig igénylik a sajtóban való megjelenést. 


\section{Összefoglalás}

nonprofit szervezetek nagy többségét idős vagy idősödő helyi lakosok vezetik, A akik korábban is valamilyen formában - alpolgármester, önkormányzati képviselố, iskolaigazgató vagy egyéb tisztségben - közszereplôi voltak a kisvárosnak. A nonprofit szervezetek tagsága, az önkormányzat és a város vezetô rétege (helyi vállalkozók, kereskedők, élénk társadalmi életet élők) nagymértékủ átfedést mutat. Kiki megjelenik itt is, ott is. Mindenki ismer mindenkit és nagymértékben elgondolkoztató, hiszen a helyi szervezetek elsősorban (különbözố okok miatt) az önkormányzat támogatására támaszkodnak. Ezt tovább fokozza, hogy néhány egyesület vezetőségi tagja több helyen is szerepel, sốt az önkormányzatban is valamilyen formában jelen van. Az önkormányzatok és a civilek közötti kapcsolat leginkább az önkormányzat által évente kiosztásra kerüló elkülönített alapra való pályázásra korlátozódik mind a nonprofit szervezetek, mind az önkormányzat részéról. Az önkormányzat természetbeni támogatása szinte minden nonprofit szervezetre kiterjed, míg anyagi támogatásban elsổsorban a sport és szabadidổs tevékenységeket, illetve a vele szerzốdésben állókat részesíti. A pályázási formákat, melyek által kiegészítő forrásokhoz juthatnának, ritkán használják ki. Ettől függetlenül a szervezetek jól lefedik a város életének szervezésére, jobbítására, könnyítésére szolgáló tevékenységükkel a felmerülő szükségleteket. Tagságuk mégsem mondható nagyszámúnak, s az aktív munka és elköteleződés is leginkább csak a szervezetek vezetôjére jellemzó.

A város vezetése és a szervezeti tagság közötti átfedés ellenére a két fél között nincs valós kapcsolattartás, együttmúködés.

Elmondhatjuk tehát, hogy hipotézisünk beigazolódni látszik, de nem szabad megfeledkeznünk arról a tényrốl, hogy kutatásunk nem mondható teljesnek, így a beigazolódás is feltevés. Siklós város jellegéból azonban viszonylag nagy biztonsággal állíthatjuk, hogy az eredmények papírformaszerủen illeszkedtek a dolgozatunk alapjául szolgáló kutatásba.

\section{Jegyzetek}

'Ez a könyv: Sebestény István (2002): Önkormányzatok és a nonprofit szervezetek kapcsolata 2000. Budapest: Központi Statisztikai Hivatal.

${ }^{2}$ Nem küldtek kérdóivet a megyei önkormányzatoknak és a kisebbségi önkormányzatoknak.

3 A háború esetére hozott kivételes intézkedés egyik cikkelye szerint, a Minisztérium, ha szükségesnek látja, betilthatja az egyesületek múködését.

4 Az alkotmányban deklarált egyesülési jog az alapja az önkéntes alapon létrejövổ, szervezett társadalmi közösségek mủködésének. E szabadságjogok gyakorlását a jogrendszer azáltal biztosítja, hogy az állampolgárok önkéntes szervezôdéseit jogi személyként ismeri el. Az 1949. évi 2. sz. törvény ezt eltörölte, s újra csak az egyes polgári jogi szabályok módosításáról szóló 1987. évi 11. sz. törvény biztosított lehetôséget. (Andrássy, egyes polgári jogi szabályok módositásáról szoóló 1987. évi 11. sz. törvény biztositott lehetóséget. (Andrássy, 1993) Ennek eredményeként volt tapasztalható az alapítvány jogintézményének újbóli megjelenése. Ez le5 Az 1993 . évi XCII. törvény a Polgári Törvénykönyv egyes rendelkezéseinek módositásáról, melvet 1994 . január elsején iktattak be, biztosította a közhasznú társaságok megalapítását. Ennek oka, hogy 1996-ig, az alapítványokkal összevetve, a társaságoknak csak, mintegy negyede alakult meg.

7 1888- szepter.

\section{Felhasznált irodalom}

Alapfokú kézikönyv civil szerveztek számára (1998) Budapest: Nonprofit Információs és Oktató Központ Alapítvány - Soros - NIOK Iroda

Andrássy Lászlóné (1993): Az alapítványi intézmény története. Könyvtári Figyelö 39. évfolyam 2. szám. http:// www.ki.oszk.hu/kf/1993/2/andrassy_h.html

Bóhm Antal (1999): A XX. Századi magyar társadalom. Budapest: Korona Kiadó http:/helynevtar.ksh.hu/datapageplusz.php4?c_id=9071\&__lang $=$ hu\&sid $=1105580205982577949 \&$ tract $=3$ http://www.1000ev.hu/index.php?a=3\&param $=9034$

Kiss Z. Géza (2000): Az önkényuralom és a dualizmus kora : 1849- 1914. In. Vonyó József (szerk.): Város a Tenkes alján. Siklós: Siklósi Önkormányzat, 175- 226.

Kuti Éva (1998): Hívjuk talán nonprofitnak... Budapest: Nonprofit Kutatócsoport

Nagy Imre Gábor (2000): Siklós a két világháború között: 1921-1944. In. Város a Tenkes alján. Siklós: Siklósi Önkormányzat

Rozs András (2000): A „koalíciós korszak” Siklóson: 1944. november 29.-1950. In. Vonyó József (szerk.):Város a Tenkes alján. Siklós: Siklósi Önkormányzat

Sebestény István (1998): Önkormányzatok és a nonprofit szervezetek kapcsolata 1996. Budapest: Központi Statisztikai Hivatal

Sebestény István (2002): Önkormányzatok és a nonprofit szervezetek kapcsolata 2000. Budapest: Központi Statisztikai Hivatal

Siklósi sajtó 1988-1993 között

Szita László (2000): Siklós a török megszállás korában (1543-1686) In. Vonyó József (szerk.): Város a Tenkes alján. Siklós: Siklósi Önkormányzat

Szita László (2000): A török alóli felszabadulástól az 1848-1849-es szabadságharc bukásáig In. Vonyó József (szerk.): Város a Tenkes alján. Siklós: Siklósi Önkormányzat

Tegzes Ferenc: Siklós az elsổ világháború és az antat-szerb megszállás idôszakában. In. Vonyó József (szerk.): Város a Tenkes alján Siklós évszázadai. Siklós: Siklósi Önkormányzat, 227-244. 